\title{
Revealing the Philosophical Foundation in English Textbook for Vocational School Students Grade X and Curriculum 2013
}

\author{
Fatma Rahayu Nita ${ }^{1}$, Oikurema Purwati ${ }^{2}$ \\ Universitas Negeri Surabaya $^{1-2}$, Indonesia \\ Correspondence: Fatma Rahayu Nita, Universitas Negeri Surabaya; Indonesia. e-mail: \\ fatma.20043@mhs.unesa.ac.id \\ Submitted: January 04, 2021 \\ Revised: March 04, 2021 \\ Accepted: March 06, 2021 \\ DOI: 10.29408/veles.v5i1.3036 \\ URL: http://dx.doi.org/10.29408/veles. v5i1.3036
}

\begin{abstract}
This study attempts to reveal the philosophical foundation employed in the textbook and its relation to curriculum 2013. This study was based on the inferential content analysis, so the object was an English textbook under the title 'Forward an English Course for Vocational School Students Grade X. It applied linguistics and communication construct analysis to make an inference. Then, it recorded and categorized the data. The inferences were examined through attribution analysis. The results found ten points related to the content and the structure of the textbooks. Some philosophical foundations are found in the textbook, such as essentialism, perennialism, humanism, existentialism, social reconstruction, and progressivism. These philosophical foundations are in line with the philosophical foundations implied in curriculum 2013. Finally, both English textbooks for vocational students and curriculum 2013 are more concerned with their character and skills. The skills that should be developed to engage with this $21^{\text {st }}$ century include critical thinking, problem-solving, communication, collaboration, creativity, and innovation.
\end{abstract}

Keywords: Philosophical foundation, curriculum 2013, textbook analysis

\section{Introduction}

Since textbooks play a vital role in the teaching-learning process, teachers and students cannot be separated from the textbook. According to Tomlinson (2011, as cited in Dilla et al., 2017), the textbook is one tool that teachers and learners use to support their teaching and learning process. In this case, the Ministry of Education and Culture is standard that textbook has been provided and measured to the applicable curriculum. The curriculum has become a crucial part of education because it relates to the goals, objectives, and instruction organization (Ornstein \& Hunkins, 2018). Besides, the curriculum becomes the reflection of the philosophy that is followed by society (Alwasilah, 2014 as cited in Megawati \& Zuchdy, 2020). Indonesia 
applies a curriculum 2013 that focuses on developing soft skills, critical thinking, and problemsolving. Also, the students should be able to communicate and collaborate, make innovation, and be creative (Madya, 2013). According to Anwar (2014), Curriculum 2013 is developed based on three aspects such as philosophical, juridical, and conceptual, where those aspects are constructed using various philosophical foundations in an eclectic way (Kossasy, 2017; Suarga, 2017; Zaini, 2015). Curriculum 2013 is developed to prepare for the challenges faced in the $21^{\text {st }}$ century through philosophical foundations. It is vital to use the textbooks correlated to the philosophical foundation to reach the learning process's goals. Consequently, this study attempts to reveal the philosophical foundation in English textbooks under the title "Forward an English Course for Vocational School Students Grade X" to know that philosophical foundations in the textbooks correlate to the philosophical foundations in Curriculum 2013. The philosophical foundations implemented in curriculum 2013 are essentialism, perennialism, humanism, progressivism, social constructivism, and idealism (Tanner 1980, as cited in Hasan, 2013).

The philosophy of essentialism is based on idealism and realism, aiming to stimulate intellectual growth and educate people (Ornstein \& Hunkins, 2018). Essentialism believes that knowledge should be transferred to the students systematically. While perennialism is based on realism, which encourages the students to be critical thinkers, they think logically. Philosophy of humanism concerns the students who become the main actors to interpret their learning experiences and increase their positive potential that influences learning (Riyanton, 2015). Next is the philosophy of progressivism, which believes that the students are the center of the class and the teacher is only becoming a facilitator. Today, this philosophy is commonly used in the Educational context to make the students be active and involved in the discussion. According to Ornstein \& Hunkins (2018), this philosophy is based on the philosophy of pragmatism, which supports democratic and social living so that the teacher becomes the guidance to solve the problem. The philosophy of social constructivism is also based on the philosophy of pragmatism, but it aims to improve and reconstruct society. The main goal is to educate for the changing and social reform (Ornstein \& Hunkins, 2018). The last is the philosophy of idealism states that ideas and knowledge are the only truth, and it aims to develop students' ability to serve a better society. In this case, the teacher is the role model to handle the ideas through lecture and critical discussion.

Those philosophical foundations are the primary philosophy that must be appeared in English textbooks because it determines the learning goals, the learning process, and the role of teacher and students (Rahmatullah, 2013). The study done by Hanif (2014) has analyzed the philosophical aspects of the curriculum in 2013. It revealed that the curriculum 2013 is developed based on the philosophical foundation and educational philosophy. The results showed that perrenialism and essentialism are the focus of the study. Yet, another study done by Hasan (2013) found that curriculum 2013 is based on many philosophical foundations such as perennialism, essentialism, humanism, progressivism, and social reconstruction. A similar study has been conducted by Faris (2016) stated that progressivism becomes the dominant philosophy that correlates to curriculum 2013. The education system proves more concerned with the 
students as the center of the study while the teacher is a facilitator and the subjects are implemented in one unit. Observing that philosophy guides and develops curriculum, the textbook must align with the philosophical foundations and the curriculum.

Much research conducted a textbook analysis. Yet, it only focuses on the necessary competencies, the accuracy of the materials, or taking one of the philosophical foundations applied in textbooks. Only a few studies examined the correlation of philosophical foundations in English Textbooks and curriculum 2013. To give examples, a few of them are Hastuti (2020) and Megawati \& Zuchdy (2020). Hastuti (2020) has examined Bahasa Inggris XI's philosophic foundation and its compatibility with curriculum 2013. This study is conducted in Indonesia, which uses five main chapters and three enrichment chapters. The results revealed six philosophic foundations found in the Bahasa Inggris textbooks: essentialism, perennials, humanism, social reconstruction, progressivism, and idealism. However, another study done by Megawati \& Zuchdy (2020) examined the philosophical foundation of the English in Mind Students' Book and the compatibility of the philosophical foundation between the curriculum and the textbooks. It only used six chapters to be analyzed. The results found six philosophies applied in the textbook: perennialism, progressivism, essentialism, existentialism, humanism, and social reconstruction.

Both of the studies have revealed a similarity in the philosophical foundation in the textbook and curriculum 2013. Yet, the textbook analyzed by Megawati \& Zuchdy (2020), published by Cambridge Press, is not from Indonesia, so that the level of readability is different from Indonesia students. Consequently, it needs to conduct the readability of the book before applying that book in Indonesia. However, this present study uses a textbook published by Indonesian publisher, Erlangga. This study also analyzes an English textbook entitled "Forward an English Course for Vocational School Students Grade X" based on the philosophical aspects. This textbook is used for vocational school students' grade X. It is fascinating to reveal whether this textbook has referred to the philosophical foundations in Curriculum 2013 or not.

\section{Method}

This study is conducted from the end of October to December 2020. It employed qualitative analysis to describe and interpret the selected data in words, phrases, and sentences. Creswell (2009) stated that qualitative research is a form of interpretive inquiry in which the researchers describe and interpret what they see and understand. This study is included in an inferential content analysis study that aims to interpret a textbook set in a textbook that shows particular philosophical foundations in the textbook (Hastuti, 2020). Due to collecting the data through documentation, an English textbook for vocational school eleventh grade is used as the study's object. This textbook was written by Lande \& Astuti and published by Erlangga publisher in 2017. The steps to collect the data could be seen in Figure 1 below: 


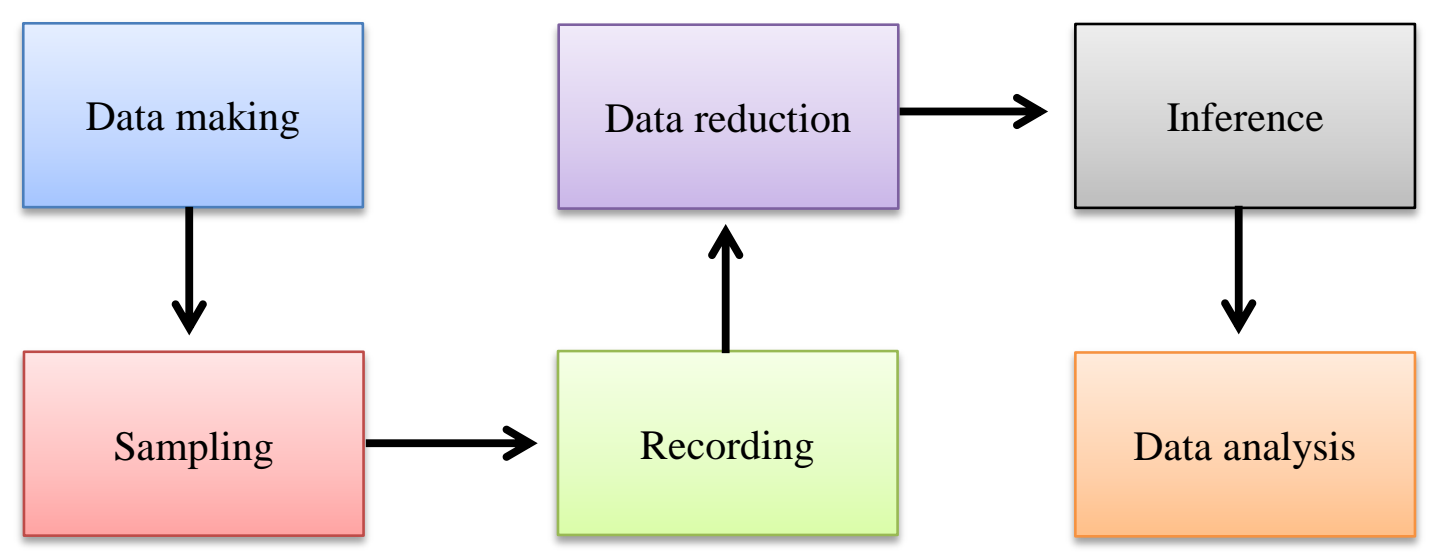

Figure 1. The Steps of collecting the data

Figure 1 shows the steps of collecting the data. The first step is data making, and it selects the units used to be examined. The second is sampling, this textbook covers thirteen units, and the sample is all the units in the textbooks. The third step is to record the data and categorize it based on the characteristics. The fourth is data reduction; it eliminates the data that is not relevant to the study's purpose. The fifth is the analysis of the data that has been selected based on the theory by (Ornstein \& Hunkins, 2018).

\section{Results and Discussion}

This section serves the results of the study followed by a discussion. The data analysis is based on the sentence of the unit's task and decides the philosophy types. The sentences in the text are analyzed to understand the instruction. The materials provided in the textbooks are wellstructured, starting from the introduction, the tasks, and the reflection. The materials are divided into thirteen units. Each unit contains a pronunciation center, interlude, brainteasers, essential grammar, writing activity, and level up.

The materials given reflect on learning in the classroom, starting from 'Hello, Everyone' until the last material, 'You Should Get Some Rest.' It also relates from one skill to another, such as writing, speaking, listening, and reading. The materials given are related to real-life that can build their character and skills in the 21st century, such as critical thinking, problem-solving, collaboration, communication, creativity, and innovation. The students are guided to work independently and in a team to enhance their communication and collaboration skills. The students are guided through analyzing the particular situation based on the text, discuss with the partner or group, and present the results verbally and verbally. The students are free to select the topics discussed with their friends. The students are free to define what to do, such as making a dialog or role play, presentation, or other activity related to the topic. The students individually are guided to find the main idea related to the moral values that have been provided in the texts. The students individually are guided to develop their idea related to a particular topic's values. Finally, the students are guided to reflect on what has been in the learning process, so teachers help them engage with the problematic materials. 
Based on the analysis results above, it is essential to find the task that reflects on the philosophical foundation. Therefore, the example of a task that relates to the philosophical foundations is provided and discussed as follows:

\begin{tabular}{lll}
\hline Units & Task & Instruction Sentence \\
\hline 2 & 15 & Write a congratulation letter on one of the following situations \\
& a. Your friend gave a good performance \\
& b. Your friend got a job a week ago \\
& c. Your friend won a Karate championship and got a gold \\
& national medal \\
\hline
\end{tabular}

Figure 1 The example task that reflects on the philosophy of Existentialism

It could be seen in Figure 1; students are asked to make dialogs based on the given situations. There are three situations provided in the task. In this case, students are free to select the situations that may reflect on their own experiences. The previous study done by Ekawati (2015) stated that the philosophy of existentialism should give freedom to each individual to do because they have their interest and interest. Thus students can make choices and define themselves. Existentialists make the students free to choose how and what they study (Ornstein \& Hunkins, 2018, p. 50). It clearly shows that the textbook's task reflects the philosophy of existentialism. Other than that, the task implicitly guides the students to be critical thinking because it does not require individual work but work in pairs. It means the students should have good communication skills and think critically to work together. The discussion process gives the students a chance to develop their ideas and listen to another idea. This kind of activity helps the students communicate and collaborate. Existentialists believe that there is no imposition of group norms, and authority, as well as opinions, are indisputable (Ornstein \& Hunkins, 2018, p. 51). In brief, an existentialist curriculum involves the experiences and subjects that allow students to have their own choices and free to decide.

\begin{tabular}{lll}
\hline Units & Task & Instruction Sentence \\
\hline 7 & 17 & $\begin{array}{l}\text { Read the following text about R.A Kartini aloud. Take turns reading with a } \\
\text { friend. Pay attention to the correct pronunciation }\end{array}$ \\
& & $\begin{array}{l}\text { Discuss the following questions with your friends } \\
\text { a. What is your opinion on the influences of R.A Kartini? } \\
\end{array}$ \\
& b. How would you describe R.A. Kartini? \\
& c. How do you think she contributed to modern Indonesian women and what \\
& impact has she had on the country?
\end{tabular}

Figure 2 The example task that reflects on the philosophy of Essentialism

As the Figure 2, the students are asked to read the text about R.A. Kartini. The text contains the historical background of R.A. Kartini as well as a moral value that has been promoted by R.A. Kartini a couple of years ago. The instruction implicitly teaches the students 
the traditional moral values of R.A. Kartini. This finding is in line with the concept of the philosophy of essentialism promoted by William Bagley that philosophy of essentialism encourages individuals' intellectual development, educates them, and teaches traditional moral values and knowledge (Ornstein \& Hunkins, 2018, p. 68). Other than that, the philosophy of essentialism gives the students space to develop their communication skills logically (Junaidin \& Komalasari, 2019). The textbook's task instructs the students to give their opinion about R.A. Kartini and how R.A Kartini contributes to Indonesia. In this case, the students can read the text, discuss it with their friends, and share their opinions. This kind of activity allows the students to show the traditional moral values of R.A. Kartini to the classmates and teachers, and they can learn from that.

\begin{tabular}{ccc}
\hline Units & Task & Instruction Sentence \\
\hline 8 & 14 & Read the legend to answer the following questions. \\
& & a. What is the orientation of the text? \\
b. What is the complication? \\
c. Could you tell the sequence of the events in brief? \\
\end{tabular}

Figure 3. The Example task that reflects on the philosophy of perennialism

In Figure 3, the textbook provides the text under the title "legend of Batu Bagga." As stated in the textbook that the primary goal of presenting the text is to use moral values in the stories. Therefore, some classical texts are in the textbooks. This material is inconsistent with the concept of Philosophy of Perennialism that perennialism uses classical subject to educate students and the literary analysis as the curriculum used in the perennialism (Ornstein \& Hunkins, 2018). According to perrenialists, it is crucial to study the past's great ideas because it guides the students to welcome the present and cope with the future. In particular, perennialism treats human nature as rational and believes that knowledge is unchanging. In this case, the textbook serves many texts that lead the students to read, understand, and implement their moral values. As seen in Figure 3, the students are instructed to read the Legend of Batu Bagga's story, and the students must be able to answer the questions based on texts. One of the questions related to the moral value of the story. Therefore, it can be concluded that the material of the textbook contains the philosophical foundation of perrenialism.

\begin{tabular}{ccl}
\hline Units & Task & Instruction Sentence \\
\hline 1 & 1 & What are your dreams? Write down your plans or dreams for your future \\
& 2 & Now ask the same question to five of your friends. What are their dreams? \\
\hline
\end{tabular}

Figure 4. The example task that reflects on philosophy of humanism

Philosophy of humanism views education that emphasizes the students as the class's subject. According to Riyanton (2015), humanistic education allows students to choose what they want and do positive things. In this case, the students as human beings are free to express 
their ideas and select the right ideas based on their experiences. It could be seen in Figure 4: the students are asked to write their dreams and their plans for the future. The students are given an example, but they freely express and decide what they want to be in the future. This kind of task allows the students to consider their dreams. Afterward, they can share their ideas with other friends to communicate and collaborate to discuss their dreams. These results align with what Riyanton (2015) stated: education should take a human as a social being who can interact, grow, and develop based on their potentials. Humanism is often associated with the educational concepts promoted by Ki Hadjar Dewantoro "Ing Ngarso Sung Tulodo, Ing Madyo Mangun Karso, Tut Wuri Handayani." It covers all the aspects of humanities that we should appreciate, and respect's humanities and cooperative learning are aspects of humanistic education. According to Nurjanah (2018), humanism regards a philosophical foundation that positions humans as the highest subject to freely express their thoughts and enhance their abilities and potentials. This philosophical foundation is involved in the textbooks because they are instructed to develop their opinions based on their needs and interests.

\begin{tabular}{ccl}
\hline Units & Task & Instruction Sentence \\
\hline 13 & 12 & $\begin{array}{l}\text { Work in pairs. Advise the people in the following scenarios on how they should } \\
\text { do or what course of action they should take in their particular situation. } \\
\text { Make a dialog with your friend using the following examples. Make as many } \\
\text { suggestions as you can }\end{array}$ \\
\end{tabular}

Figure 5 The example task that reflects on the philosophy of social reconstruction

As shown in Figure 5, the students are asked to work in pairs to solve the problems. It has been provided the scenario, and the students must analyze the problem and what kind of solution is appropriate in the scenario. In this task, the students should be aware of the problems that are faced by humankind. Students must be involved in solving the problem to play a role in society. As stated by Ornstein \& Hunkins (2018), in the philosophy of social reconstruction, the teacher becomes the agent of change and plays a role in helping the students solve the problem. The teacher can give some examples related to answering the task through the textbook. Teachers and students work together to create, improve and reconstruct society. The philosophy of reconstruction educates the people, improves and reconstructs society, and social reform (Ornstein \& Hunkins, 2018). The textbook has presented the philosophy of social reconstruction. It can be seen through each unit in the textbook that provides various tasks in the group. The students collaborate to answer the question and solve the problems.

1327 Read and reply the following letter.

Level Up!

a. Giving advice

b. Responding to advice

c. Making offers

d. Responding to offers

Figure 6. The example task that reflects on the philosophy of progressivism 
It found the philosophy of progressivism is included in the textbook. It can be realized through pronunciation, listening, reading, grammar, brainteasers, and level up. One example provided in Figure 6 is that the students are asked to read and reply to the letter. In this case, the students can give advice and how to respond to the advice. It is included in the activity of problem-solving; according to Oinstein dan Levine (1985, as cited in Al Faris (2016), teachinglearning should be active, exciting, and everchanging as the concept of progressivism. Besides, the students can reflect on themselves about their materials' capability. Level up section is significant for the students to measure whether they understand the material. According to Fadlillah (2017), progressivism emphasizes problem-solving. The education offers students opportunities to learn individually and work in a team to learn together through the experience (Jalaludin \& Idi, 2012).

The results prove a relation between philosophical foundations in Textbook for Vocational students with the curriculum 2013. Curriculum 2013 refers to the skills of the $21^{\text {st }}$ century, which emphasizes critical thinking, the ability to adapt to the environment dynamically, and the growing of character that meets the country's culture (Machali, 2014). In the $21^{\text {st }}$ century, students are prepared to meet the challenges in the era. Therefore, the textbook is appropriate for developing critical thinking, problem-solving, collaboration, communication, creativity, and innovation as curriculum 2013 promoted.

\section{Conclusion}

Based on the results, there is a relation between the philosophical foundation of the curriculum 2013 and the textbook. Both contain the philosophy of perennialism, essentialism, humanism, progressivism, and social reconstruction. The textbook must be in line with the applicable curriculum to achieve the learning goals and objectives. The aspects that appear in curriculum 2013 are provided in the textbook. It means that the textbook supports the classroom's English and learning process. This paper has also reviewed how the structure of the textbook implements some philosophical foundation to a curriculum. Thus, this paper can be the guidance to examine philosophical studies in depth. One of the study's drawbacks is that it is limited to the textbooks for a vocational school. Thus, it could not be generalized into the books published by the Ministry of Education and Culture. It needs to obtain the information related to all textbooks' compatibility and English textbooks. Therefore, further study can conduct another book to be compared with the English textbook. Finally, this study is used to do the same research in-depth.

\section{References}

Al Faris, F. (2016). Kurikulum 2013 dalam perspektif filsafat pendidikan progressivisme. Jurnal Filsafat, 25(2), 316-338. Https://doi.org/10.22146/jf.12687

Anwar, R. (2014). Hal-hal yang mendasari penerapan kurikulum 2013. Humaniora, 5(1), 97-106. Https://doi.org/10.21512/humaniora.v5i1.2987

Creswell, J. W. (2009). Research design-qualitative, quantitative, and mixed approaches. $\left(3^{\mathrm{rd}}\right.$ 
ed). Thousand Oaks,CA: Sage Publications.

Dilla, R. G., Damayanti, I.-, \& Hati, G. M. (2017). The content analysis of bahasa Inggris textbook for senior high school grade $\mathrm{X}$ published by Kemendikbud 2014. Journal of English Education and Teaching, 1(1), 1-8. Https://doi.org/10.33369/jeet.1.1.1-8

Ekawati, D. (2015). Eksistensialisme. Jurnal Tarbawiyah, 10(2), 75-84.

Fadlillah, M. (2017). Aliran progresivisme dalam pendidikan di Indonesia. Jurnal Dimensi Pendidikan

Dan

Pembelajaran,

$5(1)$

$17-24$.

Http://journal.umpo.ac.id/index.php/dimensi/article/view/322

Hanif, M. (2014). Tinjauan filosofis kurikulum 2013. Insania, 19(1), 87-114. Https://doi.org/10.24090/insania.v19i1.465

Hasan, S. H. (2013). Landasan filosofi kurikulum 2013. Makalah Presentasi.

Hastuti, S. D. S. (2020). Keselarasan landasan filosofis buku ajar 'bahasa Inggris' dengan landasan filosofis pada kurikulum 2013. Wacana Akademia: Majalah Ilmiah Kependidikan, 4(1), 64-73. Https://doi.org/10.30738/wa.v4i1.6360

Junaidin, \& Komalasari. (2019). Konstribusi esensialisme dalam implementasi kurikulum 2013. Jurnal Manajemen Dan Supervisi Pendidikan, 3(3), 137-147. Https://doi.org/10.17977/um025v3i32019p137

Kossasy, S. O. (2017). Analisis konsep dan implementasi kurikulum 2013. Ppkn \& Hukum, 12(1), 78-89.

Machali, I. (2014). Kebijakan perubahan kurikulum 2013 dalam menyongsong Indonesia emas tahun 2045. Jurnal Pendidikan Islam, 3(1), 71-92. Https://doi.org/10.14421/jpi.2014.31.7194

Madya, S. (2013). Metodologi Pengajaran Bahasa: dari Era Prametode sampai Era Pascametode. Yogyakarta: UNY Press.

Megawati, I., \& Zuchdy, D. (2020). The compatibility between philosophy basis of 'english in mind' textbook and curriculum 2013. VELES Voices of English Language Education Society, 4(2), 163-176. Https://doi.org/10.29408/veles.v4i2.2555

Nurjanah, I. (2018). Paradigma humanisme religius pendidikan islam: Telaah atas pemikiran Abdurrahman Mas'ud. MISYKAT: Jurnal Ilmu-Ilmu Al-Quran, Hadist, Syari'ah Dan Tarbiyah, 3(1), 155-170. Https://doi.org/10.33511/misykat.v3n1.155

Ornstein, A. C., \& Hunkins, F. P. (2018). Curriculum: foundations, principles, and issues. Boston: Pearson Education Limited.

Rahmatullah. (2013). Landasan pengembangan kurikulum 2013. Ta 'limuna, 2(2), 123-135.

Riyanton, M. (2015). Pendidikan humanisme dan implementasinya dalam pembelajaran bahasa Indonesia. Jurnal Ilmiah Lingua Idea, 6(1), 1-18. Http://jos.unsoed.ac.id/index.php/jli/article/view/327

Suarga, S. (2017). Kerangka dasar dan landasan pengembangan kurikulum 2013. Inspiratif Pendidikan, 6(1), 15. Https://doi.org/10.24252/ip.v6i1.3579

Zaini, H. (2015). Karakteristik kurikulum 2013 dan Kurikulum Tingkat Satuan Pendidikan (Ktsp). Jurnal Idaroh, 1(01), 15-31. 